\title{
LIFE FORMS AND LIFE STRATEGIES IN NANOCYPERION COMMUNITIES FROM THE NETHERLANDS FRISIAN ISLANDS
}

\author{
H. J. DURING
}

Vakgroep Vegetatiekunde en Botanische Oecologie, Heidelberglaan 2, 3584 CS Utrecht

\section{SUMMARY}

Nanocyperion communities (s.l.) are considered here as "warp-and-woof" communities; the Nanocyperion components are described separately as synusiae. On the Netherlands Frisian Islands, four main synusiae have been recognized. Raunkiaer life form spectra show few differences between the communities. Life strategy spectra of the Nanocyperion synusiae, based on systems for phanerogams (modified after BAKKER 1966) and bryophytes, yield the clearest patterns. A comparison of the ecology of the communities and an interpretation of the spectra in terms of avoidance of stress or competition suggest that inundations and standing crop of the communities are the main factors determining the distribution of the synusiae. Winter inundations overrule the influence of differences in productivity level, which becomes prominent in drier situations.

\section{INTRODUCTION}

Life form and life strategy systems are meant to reflect certain adaptations to the habitat of the plants (e.g., RAUNKIAER 1904, 1934, IVERSEN 1936, MACARTHUR \& WILSON 1967, GRIME 1979). The choice of the system used determines to a large extent, which information is yielded by spectra showing the proportion of life form or life strategy categories in communities. The aim of this paper is to show that insight in the ecology of Nanocyperion communities may be gained by turning to life strategies focusing on life cycle period, regeneration and colonisation.

The communities of the alliance Nanocyperion flavescentis are characterized by a group of consistently very small, hapaxanthous plants and a considerable number of bryophytes.

In The Netherlands the Nanocyperion has been studied by Diemont et al. (1940). Since then, these communities have become very rare, like elsewhere in W. and Central Europe, though on the Netherlands Frisian Islands several of them are still fairly well represented.

The communities are found at the margins of lakes and ponds, on sand banks in rivulets, in dune valleys, in ditches in moist arable fields. They also occur in situations with a rather high level of "disturbance" such as drinking places of cattle, car tracks, paths, and grazed parts of salt-marshes. They belong to the "warp-and-woof communities" sensu TüXEN \& LOHMEYER 1962; in such communities the warp component is outcompeted quickly or destroyed annually, but it maintains itself by shifting to other, regularly occurring, suitable microsites in the phytocoenosis (shuttle succession ("Pendelsukzession") sensu TüxeN \& 
WeSTHOFF 1963). This shifting component may conveniently be described as a synusia sensu BARKMAN (1973).

In the well-known system of RAUNKIAER $(1904,1934)$ life forms are distinguished mainly on the place of the meristematic tissues relative to the soil surface (WHITTAKER 1962). In this system, most of the Nanocyperion species are Therophytes, while the biennials belong to the Hemicryptophytes. In the r-K continuum of MACARTHUR \& WILSON (1967), the hapaxanthous species all more or less have an r-strategy (emphasis on reproduction); an assessment of the reproductive effort per time unit might be worthwhile, but this has not yet been done. In the system of GRIME $(1974,1979)$ they all belong to the stress-tolerant ruderals.

I prefer to use a refined subdivision of the hapaxanths made by BAKKER (1966), which is based mainly on shortest life span, stage of development during winter, occurrence of seed dormancy, and vernalisation requirements. The last two characteristics are not known for all species involved and winter annuals s.l. hardly occur in the communities studied here.

Bryophytes are not easily accomodated in any life form system presented so far. In most systems they all fall into one or two categories. In the Raunkiaer system as elaborated by ELLENBERG \& MüLLER-DoMBoIs (1967) for example, the bryophytes are divided into bryo-therophytes and bryo-chamaephytes. Recently DURING (1979) tried to distinguish some categories of bryophyte life strategies based on the colonizing species groups of the Lauwerszee area in The Netherlands (JOENJE \& DURING 1977).

This system (table 2) comprises the categories fugitives (F), colonists (C), annual shuttle species $(\mathrm{Ab})$, short-lived shuttle species $(\mathrm{Sb})$, long-lived shuttle species $(\mathrm{L})$, and perennials $(\mathrm{Pb})$.

\section{MATERIAL AND METHODS}

Table 3 summarizes 102 vegetation relevés, each (10-)25-100 dm², made mainly in August-October 1971 and August 1979. A few records made in the summers of 1966, 1967, 1968, 1975, and 1976 are included. Cover-abundance measures were estimated using Braun-Blanquet classes as refined by BARKMAN et al. (1964). Also general ecological data were estimated by eye, such as a description of the surroundings, grazing and trampling intensity, salt influence, and soil profile, including (in 1971 only) $\mathrm{pH}$ at c. $1 \mathrm{~cm}$ and c. $8 \mathrm{~cm}$ depth.

The relevés were classified by hand sorting of the releve table.

Here only a synoptical table is presented, giving frequency values and median cover values of the species for each community; if a species was found in only one releve of a community, the frequency class is left out. Species occurring in three relevés or less are not listed. On the basis of the relevés made all over the atlantic dune area (DURINg 1973) and literature data (e.g., PhilipPI 1968, PietsCh 1973), it was decided which species belong to the Nanocyperion synusiae. These 22 species are listed separately at the head of the table. For calculation of the life form and life strategy spectra the cover-abundance values were transformed 
Table 1. Life strategies of phanerogams (mainly a simplified version of the system of BAKKER 1966).

\begin{tabular}{|c|c|c|c|c|}
\hline Symbol & $\begin{array}{l}\text { Shortest } \\
\text { life span }\end{array}$ & $\begin{array}{l}\text { Stage of development } \\
\text { during winter }\end{array}$ & $\begin{array}{l}\text { Hapaxanth/ } \\
\text { pollakanth }\end{array}$ & $\begin{array}{l}\text { Categories of } \\
\text { Bakker (1966) }\end{array}$ \\
\hline $\mathrm{E} 2$ & $\begin{array}{l}1 \frac{1}{2} \cdot 4 \text { months } \\
\text { (ephemerals) }\end{array}$ & $\begin{array}{l}\text { "summer dress" or } \\
\text { leaf rosette } \\
\text { seed }\end{array}$ & hapaxanth & $\begin{array}{l}\text { Al, } 2 \\
\text { A3 }\end{array}$ \\
\hline $\begin{array}{l}\text { A1 } \\
\text { A2 }\end{array}$ & $\begin{array}{l}1 \text { year } \\
\text { (annuals) }\end{array}$ & $\begin{array}{l}\text { seed (summer annuals) } \\
\text { leaf rosette (winter } \\
\text { annuals) }\end{array}$ & hapaxanth & $\begin{array}{l}\text { B1, } 2 \\
\text { B3, 4, } 5\end{array}$ \\
\hline B & $\begin{array}{l}2 \text { years } \\
\text { (biennials) }\end{array}$ & $\begin{array}{l}\text { 1st year seed; } \\
\text { 2nd year leaf rosette } \\
\text { or buds on root apices }\end{array}$ & hapaxanth & $\mathrm{Cl}, 2,3$ \\
\hline $\mathbf{P a}$ & $\begin{array}{l}\text { 1-few years } \\
\text { (pauciennials) }\end{array}$ & $\begin{array}{l}\text { various, often leaf } \\
\text { rosette }\end{array}$ & $\begin{array}{l}\text { pollakanth; in the } \\
\text { field often hapaxanth } \\
\text { due to environmental } \\
\text { constraints }\end{array}$ & - \\
\hline $\mathbf{P}$ & $\begin{array}{l}\text { several years } \\
\text { (perennials) }\end{array}$ & various & pollakanth & - \\
\hline
\end{tabular}

according to WeSTHOFF \& VAN DER MAAREL (1973).

The system of phanerogam life strategies used here is a modification of the system of BAKKER (1966). I have altered Bakker's system slightly by combining some groups. Moreover, I added the category of pauciennials (Pa) for short-lived species which may flower once, or occasionally also a few times, such as Sagina nodosa, Samolus valerandi and Carex serotina ssp. pulchella. In more southerly countries also Scirpus setaceus may be reckoned to this category. All other groups have been taken together as perennials ( $\mathrm{P}$; see table 1$)$.

As to bryophytes in the Raunkiaer life form system, I have included the bryo-hemicryptophytes distinguished by ELLENBERG \& MüLLER-DOMBOIS (1967) in the bryo-chamaephytes, since the plants remain green and alive throughout the resting season. In the system of DURING (1979), the category of the colonists

Table 2. Bryophyte life strategies with their characteristics according to DURING (1979).

\begin{tabular}{|c|c|c|c|c|c|c|}
\hline Category & $\begin{array}{l}\text { Fugitives } \\
\text { (F) }\end{array}$ & $\begin{array}{l}\text { Colonists } \\
(\mathrm{Cf}+\mathrm{Cv})\end{array}$ & $\begin{array}{l}\text { Annual } \\
\text { Shuttle } \\
\text { Species } \\
\text { (A) }\end{array}$ & $\begin{array}{l}\text { Short- } \\
\text { lived } \\
\text { Shuttle } \\
\text { Sp. (S) }\end{array}$ & $\begin{array}{l}\text { Long- } \\
\text { lived } \\
\text { Shuttle } \\
\text { Sp. (L) }\end{array}$ & $\begin{array}{l}\text { Perennials } \\
\text { (P) }\end{array}$ \\
\hline Life span (years) & $<1$ & few & $\leqslant 1$ & few & many & many \\
\hline Reproductive effort & high & high - & high & moderate & low & low \\
\hline Innovations & absent & present & absent & present & present & present \\
\hline Vegetative reproduction & absent & common & $\begin{array}{l}\text { rare or } \\
\text { absent }\end{array}$ & $\begin{array}{l}\text { rare or } \\
\text { absent }\end{array}$ & common & common \\
\hline Spore size & $<20 \mu \mathrm{m}$ & $<20 \mu \mathrm{m}$ & $>20 \mu \mathrm{m}$ & $>20 \mu \mathrm{m}$ & $>20 \mu \mathrm{m}$ & $<20 \mu \mathrm{m}$ \\
\hline
\end{tabular}




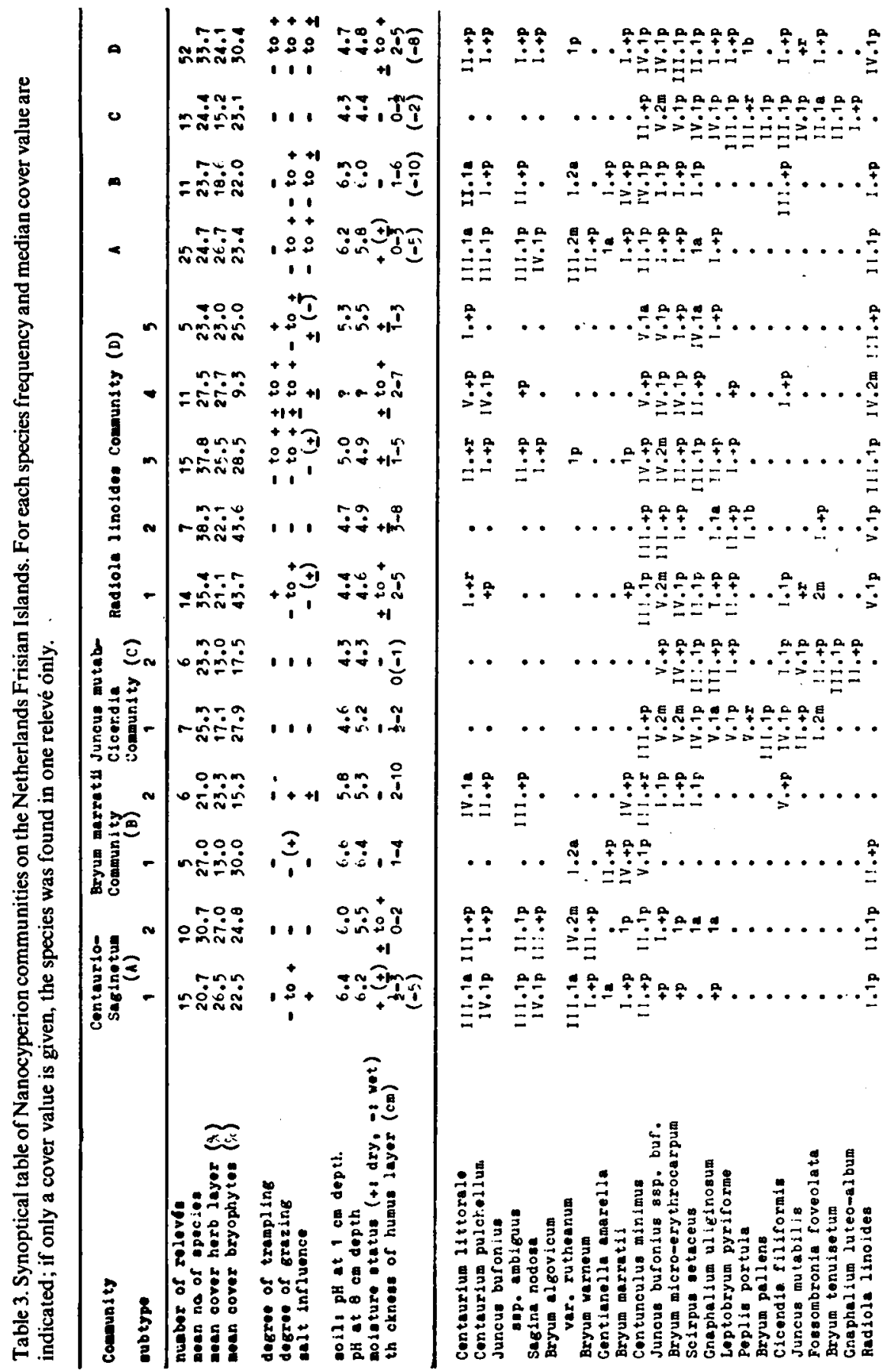




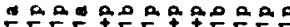

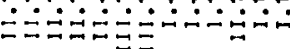

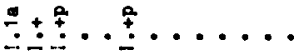

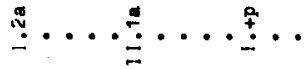

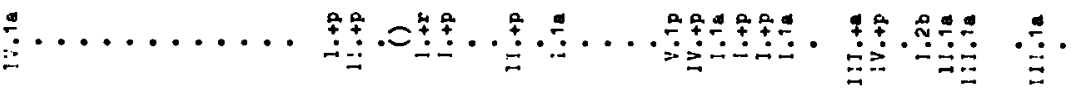

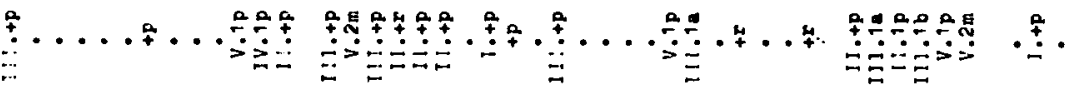

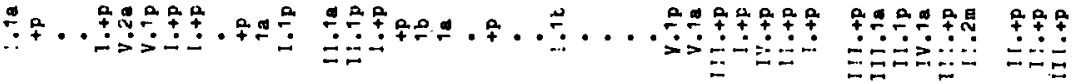

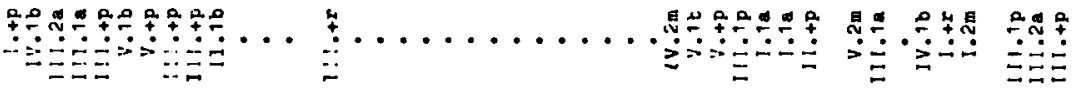

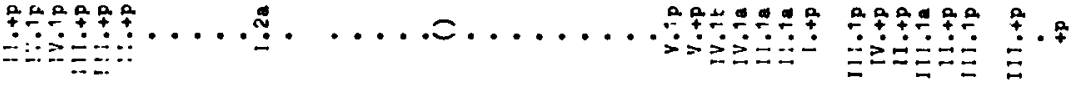

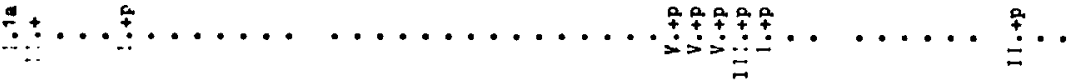

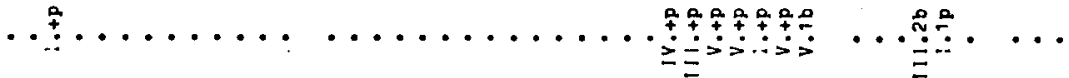

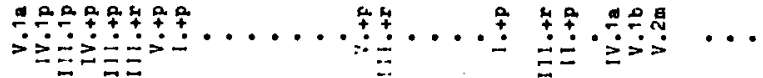

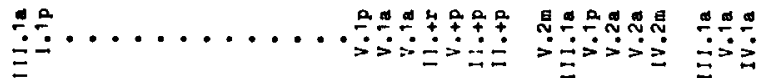

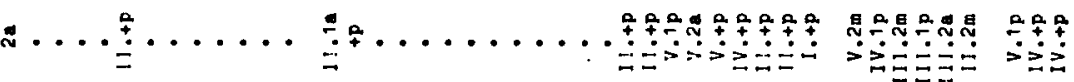

…………

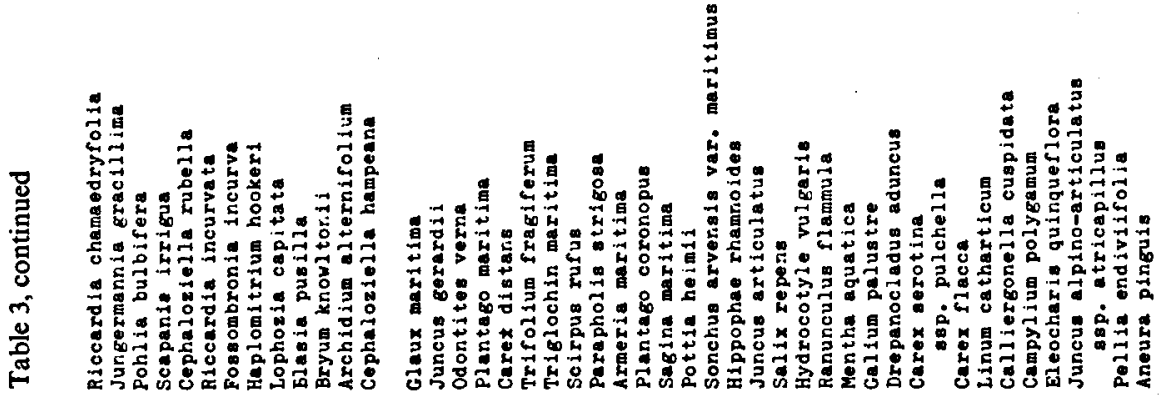




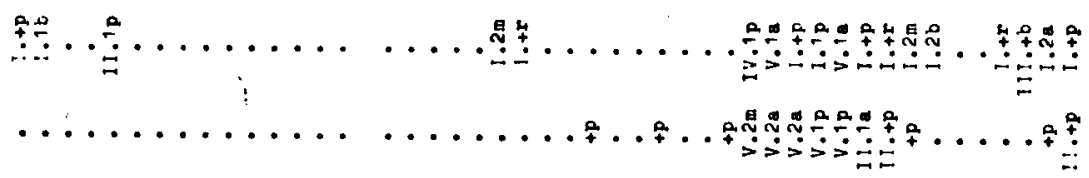

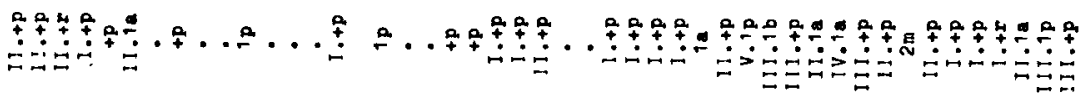

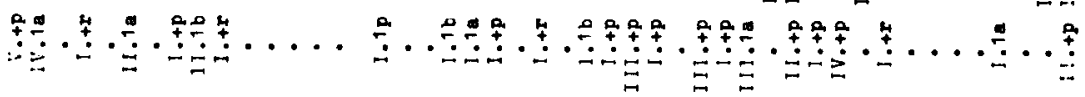

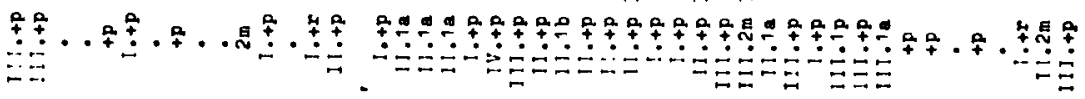

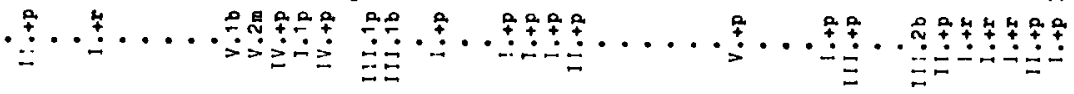

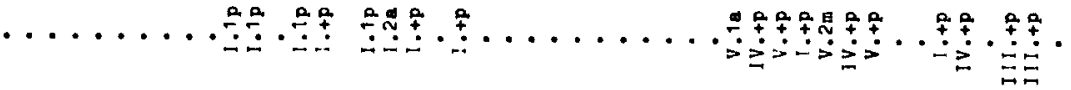

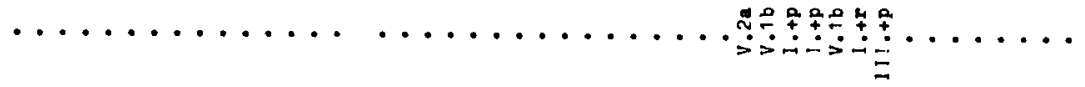

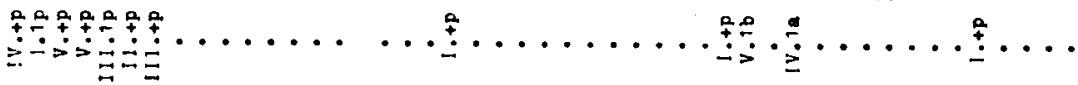

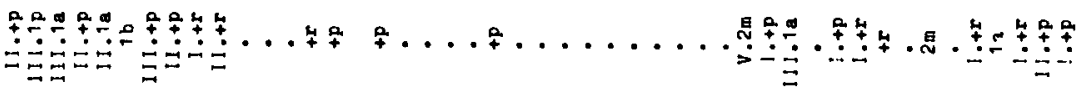
9.

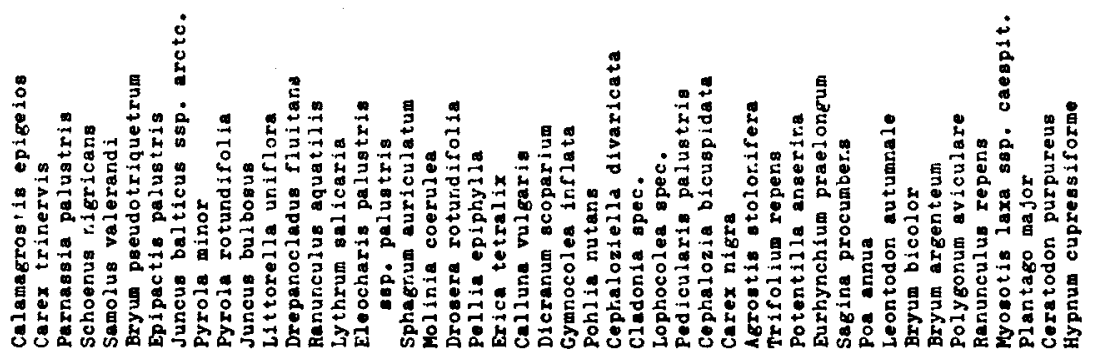




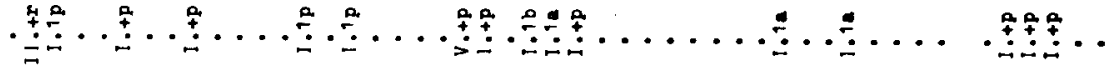

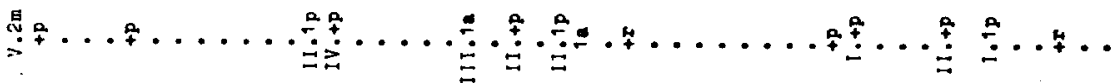

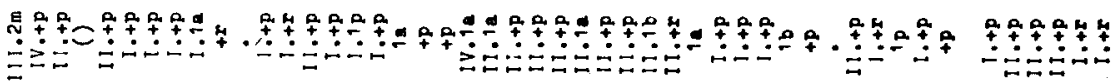

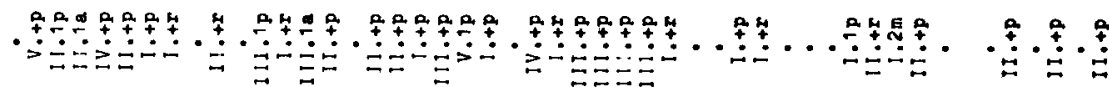

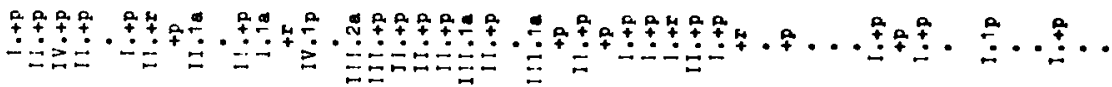

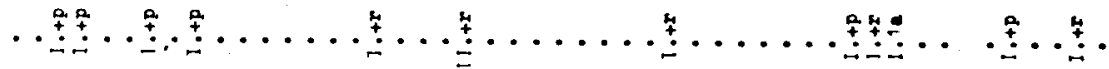

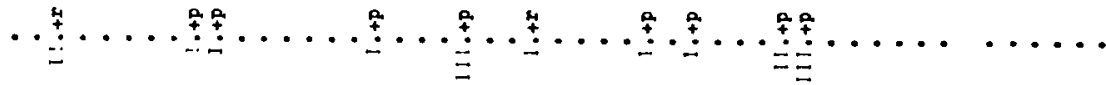

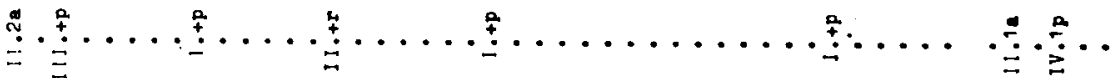

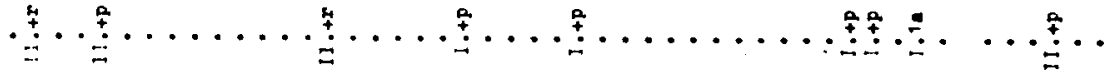

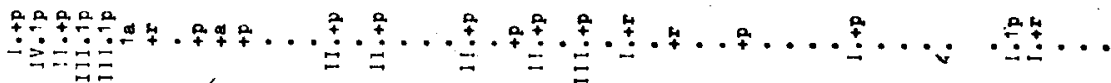

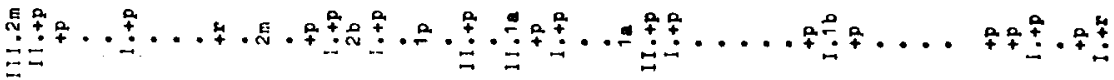

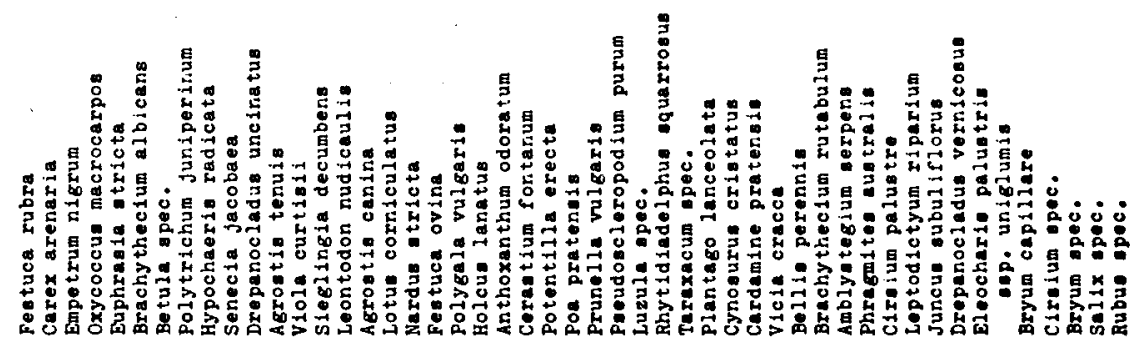


contains two subcategories which are treated separately here: species which frequently reproduce both sexually and asexually (Cf), and species which sporulate only very seldom and reproduce nearly exclusively by means of vegetative propagules (Cv.). Many species of the last subcategory are in a sense "pseudoannuals" since they often die off in the harsh season, leaving only gemmae and/or tubers. Lichens and algae, which occur occasionally in the Nanocyperion communities, have been included here in the $\mathrm{Cv}$ category (for the sake of simplicity, they have been classified as Ch-br in the Raunkiaer spectra, too).

Now the comparison of the strategy systems used here for phanerogams and bryophytes yields the following picture: $F$ (bryophytes) has no counterpart in the other system; $\mathrm{Ab}$ is comparable to $\mathrm{E} 1, \mathrm{E} 2, \mathrm{Al}$, and $\mathrm{A} 2$ of the phanerogams; $\mathrm{Sb}$ and $\mathrm{Cf}$ together may be compared to $\mathrm{Pa}$ (I do not know any strictly biennial bryophytes); and $\mathrm{Cv}, \mathrm{L}$, and $\mathrm{Pb}$ are similar to $\mathrm{P}$. It seems worthwhile to study spectra of the communities according to both strategy systems, as supposedly different ecological adaptations may be reflected.

Names of phanerogams are according to Heukels-VAN OOSTSTrOOM (1977); bryophyte nomenclature follows GROLLE (1976) for hepatics and MARGADANT \& DURING (1976) for mosses.

\section{RESULTS}

\subsection{Communities}

The relevés of the Frisian Islands can be classified into four main communities, each of which is subdivided (table 3). Since a full treatment of the Nanocyperion communities of the dunes is not yet available, I will use here provisional names only. For each synusia, the subdivisions and ecology are briefly mentioned.

\section{A. Centaurio-Saginetum moniliformis}

Ecology: on the upper parts of (frequently grazed) salt-marshes and in drier parts of young dune valleys; on sandy soil, layer of humus rather thin or absent, $\mathrm{pH} \mathrm{c}$. 6.

Subdivision: on the basis of the available material the synusia itself is not easily subdivided. However, the companion species clearly fall into two groups, by which the relevés from the salt-marshes (A1) are readily separated from those of the dune valleys (A2).

\section{B. Bryum marratii-synusia}

Ecology: on grazed salt-marshes and in wet parts of young dune valleys, nearly always near a high dune system. Probably, the high soil water table in the dune system causes the soil on the adjacent salt-marsh or dune valley to be rather constantly moist, and (on the salt-marshes) to desalinate rather quickly after inundations by the sea (cf. WESTHOFF \& MÖRZER BRUYNs 1956). The humus layer is well developed, especially on the salt-marsh; the $\mathrm{pH}$ is c.6.

Subdivision: This rare synusia may be subdivided into a species-poor form of wet 
dune valleys (B1) and a form with Cicendia filiformis and some CentaurioSaginetum species on the salt-marshes (B2); Centaurium littorale especially is rather frequent, but seldom if ever reaches the flowering stage.

\section{Juncus mutabilis - Cicendia filiformis synusia}

Ecology: On wet to moist places in young secondary dune valleys, often mingled with Littorellion species. Humus layer hardly developed; the $\mathrm{pH}$ is c. 4-4.5. Nowadays virtually confined to anthropogeneous habitats such as skating lanes in the dunes or places in wet dune valleys where sods have been cut.

Subdivision: Within the synusia, a rather species-rich form (C1) may be recognized which occurs on places with slightly higher $\mathrm{pH}$ and probably soil nutrient status (often with more human influence), and a species-poor form of more acid and nutrient-poor localities with abundant Juncus mutabilis and Fossombronia foveolata (C2).

\section{Radiola linoides synusia}

Ecology: On rather dry, open sites in secondary dune valleys, on paths and in car tracks in the dunes, also on car tracks and grazed upper parts of the salt-marshes, where inundation with salt water is rare. The sandy soil bears a moderately thick humus layer; the $\mathrm{pH}$ is c. 4.5-5.

Subdivision: The synusia shows considerable variation and can be divided into five subgroups. The first of these (D1) occurs in car tracks and on paths on acid soils without salt influence. The very species-rich relevés of D2 share the species groups of D1 and D3; this subgroup is restricted to the young dune valleys of Vlieland and open spots in older dune valleys, without grazing: trampling, or salt influence. The $\mathrm{pH}$ is intermediate between that of D1 and D3. The subgroup D3 occurs in open spots which may be caused by grazing, trampling, or cutting of sods. Salt influence is rare. The $\mathrm{pH}$ is slightly higher than in the foregoing subgroups. D4 and D5 are restricted to the uppermost parts of saltmarshes, on heavily grazed or trampled sites. In D4, Centaurium littorale is frequent, but flowers seldom. Ecologically, this subgroup is related to B2. D5 is an impoverished form of the synusia at slightly more salt-influenced, trodden places with higher $\mathrm{pH}$.

\subsection{Spectra}

The Raunkiaer life form spectra (table 4) of the communities comprising bryophytes and phanerogams are rather similar, in spite of the large floristic differences between them. The hemicryptophytes are consistently dominant, and the bryo-chamaephytes are prominent, too. All communities show a rather large proportion of therophytes compared to other dune vegetations (cf. WESTHOFF 1947); in community $\mathbf{C}$, this proportion of therophytes is greatest. $\mathbf{C}$ and $\mathbf{D}$ arecharacterized by a (small) contribution of bryo-therophytes. The "drier" communities $\mathbf{A}$ and $\mathbf{D}$ have slightly more geophytes and chamaephytes.

The phanerogam life strategy spectra (table 5) show slightly more differentiation. Community $\mathrm{C}$ stands out with a high proportion of ephemerals. The 
Table 4. Raunkiaer life form spectra of the communities, based on all species.

\begin{tabular}{lrrrrrrrrrrrrrrr}
\hline Community & A & B & C & D & A1 & A2 & B1 & B2 & C1 & C2 & D1 & D2 & D3 & D4 & D5 \\
\hline Th-Br & - & - & 1.3 & 1.7 & - & - & - & - & 0.8 & 2.0 & 0.7 & 3.3 & 2.9 & 0.2 & - \\
Ch-Br & 23.3 & 25.4 & 27.9 & 29.0 & 23.5 & 23.3 & 27.6 & 22.8 & 29.4 & 25.9 & 30.9 & 37.1 & 27.1 & 25.6 & 20.8 \\
Th & 14.4 & 12.8 & 22.4 & 13.0 & 17.8 & 10.6 & 11.8 & 13.9 & 24.6 & 19.4 & 10.7 & 7.9 & 13.7 & 17.6 & 19.8 \\
G & 3.9 & 2.2 & 0.2 & 1.8 & 1.9 & 6.1 & 3.6 & 0.6 & - & 0.6 & 0.7 & 2.5 & 2.7 & 1.2 & 1.9 \\
H & 53.2 & 56.7 & 45.3 & 48.2 & 54.8 & 51.3 & 53.4 & 60.6 & 43.8 & 47.3 & 47.4 & 40.7 & 48.6 & 53.7 & 51.2 \\
Ch & 4.6 & 2.9 & 2.5 & 5.9 & 1.4 & 8.0 & 3.6 & 2.1 & 1.4 & 4.0 & 9.0 & 8.2 & 4.4 & 1.7 & 6.3 \\
Ph & 0.6 & - & 0.4 & 0.4 & 0.6 & 0.7 & - & - & - & 0.8 & 0.6 & 0.3 & 0.6 & - & - \\
\hline
\end{tabular}

Table 5. Phanerogam life strategy spectra of the communities, based on all phanerogam species.

\begin{tabular}{lrrrrrrrrrrrrrrr}
\hline Community & A & B & C & D & A1 & A2 & B1 & B2 & C1 & C2 & D1 & D2 & D3 & D4 & D5 \\
\hline E1 & 0.5 & 0.2 & 4.6 & 1.0 & 0.4 & 0.5 & - & 0.4 & 3.8 & 5.5 & - & - & 2.2 & 1.4 & 0.8 \\
E2 & 5.3 & 8.5 & 22.0 & 8.5 & 5.8 & 4.8 & 5.8 & 11.5 & 26.3 & 16.2 & 8.3 & 5.6 & 8.4 & 9.1 & 13.1 \\
A1 & 11.7 & 8.4 & 5.1 & 9.3 & 14.7 & 8.5 & 10.4 & 6.2 & 5.0 & 5.1 & 7.3 & 7.7 & 9.0 & 12.9 & 11.1 \\
A2 & 2.5 & - & - & - & - & - & - & - & - & - & - & - & - & 0.3 & - \\
B & 2.6 & 2.2 & 0.2 & 1.3 & 3.8 & 1.3 & 0.7 & 3.8 & - & 0.4 & 1.2 & 1.4 & 1.3 & 2.8 & 0.8 \\
Pa & 11.7 & 16.9 & 6.4 & 10.7 & 10.7 & 12.8 & 15.5 & 18.5 & 9.8 & 2.0 & 7.6 & 10.0 & 10.5 & 13.8 & 16.3 \\
P & 66.9 & 63.8 & 61.7 & 69.1 & 62.1 & 72.1 & 67.6 & 59.6 & 55.1 & 70.8 & 75.6 & 75.3 & 68.6 & 59.7 & 57.9 \\
\hline
\end{tabular}

Table 6. Life strategy spectra of the bryophytes in the communities, based on all bryophyte species.

\begin{tabular}{lccccccccccccccc}
\hline Community A & B & C & D & A1 & A2 & B1 & B2 & C1 & C2 & D1 & D2 & D3 & D4 & D5 \\
\hline F & - & - & 0.8 & - & - & - & - & - & - & 2.0 & - & - & - & - & - \\
Ab & - & - & 3.7 & 5.4 & - & - & - & - & 2.7 & 5.1 & 2.1 & 8.3 & 9.7 & 0.9 & - \\
$\mathrm{Sb}$ & 34.2 & 23.5 & 0.8 & 9.5 & 33.5 & 35.1 & 31.1 & 13.0 & 1.4 & - & 4.9 & 7.2 & 6.9 & 25.3 & 13.6 \\
$\mathrm{Cf}$ & 17.3 & 18.6 & 16.8 & 22.5 & 15.1 & 19.6 & 16.1 & 22.1 & 7.5 & 30.6 & 25.6 & 24.7 & 23.2 & 9.5 & 30.3 \\
$\mathrm{Cv}$ & 12.8 & 1.1 & 35.3 & 29.4 & 15.1 & 10.3 & - & 2.6 & 40.4 & 27.6 & 39.8 & 32.6 & 22.1 & 22.2 & 22.7 \\
$\mathrm{~Pb}$ & 35.7 & 56.8 & 42.6 & 33.2 & 36.3 & 35.0 & 52.8 & 62.3 & 48.0 & 34.7 & 27.6 & 27.2 & 38.1 & 42.1 & 33.4 \\
\hline
\end{tabular}

Table 7. Combined life strategy spectra of the Nanocyperion synusiae.

\begin{tabular}{lccccccccccccccc}
\hline Synusia & A & B & C & D & A1 & A2 & B1 & B2 & C1 & C2 & D1 & D2 & D3 & D4 & D5 \\
\hline Ab & - & - & 3.5 & 6.9 & - & - & - & - & 2.4 & 5.8 & 2.7 & 13.7 & 13.7 & 0.8 & - \\
Sb & 28.1 & 23.8 & - & 6.6 & 24.3 & 33.3 & 33.3 & 16.9 & - & - & 4.0 & - & 3.4 & 20.6 & - \\
Cf & - & - & 1.2 & 9.8 & - & - & - & - & - & 3.4 & 16.2 & 17.7 & 5.0 & 4.9 & - \\
Cv & 10.7 & 2.0 & 33.1 & 30.2 & 8.7 & 13.3 & - & 3.4 & 35.3 & 28.7 & 36.2 & 42.9 & 28.1 & 19.0 & 20.3 \\
E2 & 19.9 & 45.5 & 51.2 & 24.6 & 19.4 & 20.7 & 38.1 & 50.8 & 53.3 & 47.1 & 23.5 & 13.7 & 27.7 & 23.5 & 44.6 \\
A1 & 18.8 & 18.8 & 11.0 & 19.0 & 21.4 & 15.3 & 28.6 & 11.9 & 9.0 & 15.0 & 16.5 & 12.0 & 18.7 & 23.9 & 32.4 \\
B & 9.0 & 9.9 & - & 2.6 & 11.6 & 5.4 & - & 17.0 & - & - & 0.9 & - & 2.2 & 7.3 & 2.7 \\
Pa & 13.5 & - & - & 0.3 & 14.6 & 12.0 & - & - & - & - & - & - & 1.2 & - & - \\
\hline
\end{tabular}


"drier" communities A and D (mainly D4 and D5) have more summer annuals, biennials and pauciennials. Community $\mathrm{B}$ is intermediate in most respects, though here the proportion of pauciennials is highest.

The bryophyte life strategy spectra (table 6) show more pronounced differences. Community $C$ is not outstanding here. $C$ and D1-3 are characterized by the annual shuttle species and the colonists, whereas A, B, and D4 are rich in short-lived shuttle species, and D5 is intermediate in these respects.

When spectra are calculated of the Nanocyperion synusiae only using a combination of bryophyte and phanerogam life strategies (table 7), the pattern comes out even clearer. The summer ephemerals (E2) show a clear optimum in the "wet" synusiae B and C. The biennials (Centaurium littorale only) concentrate in A, B2 and D4, and the pauciennials (Sagina nodosa only) are restricted to A. Both biennials and pauciennials are correlated positively with the short-lived shuttle bryophytes, negatively with the annual shuttle bryophytes and the colonists.

\section{DISCUSSION}

Fundamentally, the life strategy of hapaxanths may be characterized as "avoidance" of stress or competition (GRIME 1979), and in this they are opposed to the tolerance of perennials. The hapaxanths may be divided into:

I. strategies for mainly avoiding seasonal stress, the winter for summer annuals, the dry summer months for winter annuals: A1, A2. Many bryophytes of the Cv category come close to the $\mathrm{Ab}$ group in this respect.

II. strategies for mainly avoiding competition, either on a very short time scale (ephemerals), or on a longer time scale (biennials). Pauciennials show much resemblance to the biennials. In The Netherlands, the summer ephemerals avoid both competition and seasonal stresses, but due to the short summer they rarely have more than one or two generations per year, which makes them resemble annuals closely. In the communities treated here, the stress-avoiding strategies E2, A1, Ab (+ partly Cv) are concentrated in the synusiae of Juncus mutabilis Cicendia filiformis and Radiola linoides, while the categories $\mathrm{B}, \mathrm{Pa}$ and $\mathrm{Sb}$ are more or less restricted to the Centaurio-Saginetum and the Bryum marratii synusia.

All Nanocyperion hapaxanths remain very small and grow slowly. In view of their longer growing season, the annuals probably grow at an even slower rate than the ephemerals. The biennials and pauciennials should produce enough organic matter during the first growing season to survive at least one season of stress, and in the subsequent year produce a considerable amount of seeds (cf. HART 1977). Besides, they generally grow to a slightly larger size in the first year than the shorted-lived species. Consequently, both ephemerals and biennials will grow faster than the annuals treated here. It may be expected, therefore, that annuals may occur in even less productive communities than the categories. In the present study, nutrient status of the soil and productivity of the communities have not been determined, but $\mathrm{pH}$-values and comparison with literature data 
(KETNER 1972,JEFFERIES 1977, JOENJE \& WOLFF 1979) are circumstantial evidence.

When considering the combined strategy spectra of the Nanocyperion synusiae from these view-points, the following tendencies emerge.

Centaurio-Saginetum: in this synusia, the group of biennials and pauciennials dominates strongly. This is in accordance to its habitat: young, moderately productive, seldom inundated habitats in dune valleys or potentially highly productive salt-marshes (KETNER 1972) which are grazed or disturbed by winter storms; the high $\mathrm{pH}$ also points in this direction.

Bryum marratii synusia: characterized by a combination of short-lived shuttle species, ephemerals, summer annuals, and (seldom flowering) biennials. This diversity in life strategies is the more remarkable, since both the synusia and the community as a whole are rather poor in species. It is found in productive sites which are grazed intensively and may be inundated sometimes in winter. High $\mathrm{pH}$ and soil moisture availability also indicate a high productivity level.

Juncus mutabilis - Cicendia synusia: characterized by a high proportion of annuals and ephemerals. The sites are inundated for a long time during winter. The fertility of the wet to moist substrate, slightly enriched by the inundations, is apparently high enough to allow the ephemerals to complete their life cycle. In the species-poor subgroup $\mathrm{C} 2$, with very low $\mathrm{pH}$ and little or no disturbance, annuals become more prominent.

Radiola linoides synusia: here, the annuals ( $\mathrm{Al}, \mathrm{Ab}, \mathrm{Cv}$ partly) reach their highest values, though ephemerals still abound. The synusia is met with on drier, acid, soils with high humus contents and low soil fertility. The subgroup D4 resembles B2 both in habitat and strategy spectrum. The ecological differences between these two communities remain as yet unclear.

The general tendency is, that in moist to wet situations stress-avoiding strategies dominate (E2, $\mathrm{A} 1$ ), and $\mathrm{B}$ and $\mathrm{Sb}$ (if present) rarely reach the flowering c.q. sporulating stage. The main seasonal stress is here constituted by winterly inundations resulting in a short growing season, lower soil temperatures in spring, and bad aeration of the soil. In drier sites, the strategies $\mathrm{Sb}, \mathrm{Cv}, \mathrm{B}$, and $\mathrm{Pa}$ become more prominent and standing crop differences are reflected more strongly in the spectra. Here the main seasonal stress is winter cold.

In conclusion, it may be stated that a comparison of plant communities on the basis of life strategies of the species may lead to the generation of hypotheses on the environmental aspects and the functioning of these communities as well as on the main limiting factors determining these ecosystems. In a warp-and-woof community, it is likely that the "shuttle-synusia" and the perennials are determined by different ecological factors due to differences in rooting depth and responses to seasonally induced stresses (cf. WERGER 1978). This is clearly reflected in their strategy spectra.

It may be worth while to establish a combined system in which colonizing strategies as well as life cycle period and avoidance type are reflected. The ecological value of the system would be optimized especially, if the other criteria used by BAKKER (1966) could be incorporated for both plant groups. These criteria, i.e. occurrence of seed dormancy and vernalisation requirements are 
important adaptations to seasonal stress and do occur in some bryophyte groups (DuRING 1979). Their relative importance and distribution over the bryophyte taxa remains as yet unknown.

Several of the communities treated here belong to the most species-rich vegetations of the dunes. This high diversity cannot be explained satisfactorily by the corridor model of GRIME (1979), since the stands often adjoin vegetations with approximately the same productivity level but a much lower diversity. In both this corridor model and the hypothesis of GRUBB (1977) concerning the partitioning of the regeneration niche, a suppression of dominance in the vegetation is important for the existence of a high diversity in certain vegetations. This point is elaborated in a more general hypothesis of species diversity presented by HusToN (1979), which culminates in a two-dimensional model relating species diversity to frequency of population reduction and rate of competitive displacement. Beside the frequency of the population reduction, its distribution over the seasons and its predictability will also have influence on diversity (cf. GRUBB 1977). Animal effects are very important in this respect (cf. WHITTAKER 1977).

Though it is not yet possible to place exactly specific communities on the axes in the model, the general trends indicate that the Nanocyperion communities are in good accordance to Huston's predictions; the highest diversity occurs at rather low levels of growth rates and population reduction frequencies, and at higher growth rate levels a higher frequency of population reduction through grazing and seasonal climatic effects is necessary for the establishment of the Nanocyperion shuttle community which is partly responsible for the local raise in diversity (cf. tables 3,7 ).

Careful field observations may yield more information on the applicability of Huston's model; a rigid testing of his hypothesis will require field experiments in which the effects are studied of harvesting of the production and trampling, both at different frequencies and intensities, upon diversity of species and of life strategies in the community.

\section{ACKNOWLEDGEMENTS}

I am greatly indebted to the late Prof. Dr. D. Bakker, who educated me in ecology and guided the main part of the research project partly reported upon here; to him this paper is dedicated.

Drs. G. Zijlstra I want to thank for valuable information and discussions. I am grateful to Dr. W. Joenje and Dr. J. H. Willems for stimulating discussions on life strategies and related subjects.

Prof. Dr. M. J. A. Werger critically read the manuscript and proposed several improvements.

\section{REFERENCES}

BAKKeR, D. (1966): On life forms of hapaxants in the Dutch flora. Wentia 15: 13-24.

BARKMAN, J. J. (1973): Synusial approaches to classification. In: Handbook of Vegetation Science V: Ordination and Classification of Communities (R. H. WHITTAKER ed.). Junk, The Hague, pp. 437-491.

-, H. DoING \& S. SEgal (1964): Kritische bemerkungen und Vorschläge zur quantitativen Vegetationsanalyse. Acta Bot. Neerl. 13: 394-419.

Diemont, W. H., G. Sissingh \& V. Westhoff (1940): Het Dwergbiezenverbond (Nanocyperion 
flavescentis) in Nederland. Ned. Kruidk. Arch. 50: 215-284.

DURING, H. J. (1973): Het Nanocyperion flavescentis in de duinen, in atlantisch verband bezien. Mimeographed report, Dept. of Plant Ecology, Haren (Gr.).

-, (1979): Life strategies of bryophytes: a preliminary review. Lindbergia 5: 2-18.

EllenderG, H. \& D. Müller-Dombois (1967): A key to Raunkiaer plant life forms with revised subdivisions. Ber. geobot. Inst. ETH, Stftg. Rübel 37: 56-73.

Grime, J. P. (1974): Vegetation classification by reference to strategies. Nature, Lond. 250: 26-31.

-, (1979): Plant strategies and Vegetation Processes. Wiley \& Sons, Chichester etc.

Grolle, R. (1976): Verzeichnis der Lebermoose Europas und benachbarte Gebiete. Fedde's Repert. 87: $171-279$.

GRUBB, P. J. (1977): The maintenance of species-richness in plant communities: the importance of the regeneration niche. Biol. Rev. $52: 107-145$.

HART, R. (1977): Why are biennials so few? Amer. Natur. 111 : 792-799.

Heukels, H. \& S. J. van Ooststroom (1977): Flora van Nederland, 19th ed. Wolters-Noordhoff, Groningen.

Huston, M. (1979): A general hypothesis of species diversity. Amer. Natur. 113: 81-101.

IVERSEN, J. (1936): Biologische Pflanzentypen als Hilfsmittel in der Vegetationsforschung. Munksgaard, Kфbenhavn.

JEFFERIEs, R. L. (1977): Growth responses of coastal halophytes to inorganic nitrogen. J. Ecol. 65: 847-865.

JOENJE, W. \& H. J. DURING (1977): Colonisation of a desalinating Wadden-polder by bryophytes. Vegetatio 35: 177-185.

- \& W. J. WolfF (1979): Functional aspects of salt marshes in the Wadden Sea area. In: Flora and vegetation of the Wadden Sea (W. J. WolfF ed.), Stichting Veth, Leiden, pp. 161-170.

KeTNER, P. (1972): Primary production of salt-marsh communities on the island of Terschelling in The Netherlands. Thesis Nijmegen.

MacArthur, R. H. \& E. O. WiLson (1967): Theory of Island Biogeography. Princeton Univ. Press, Princeton.

Margadant, W. D. \& H. J. DuRING (1976): Beknopte blad-en levermosflora van Nederland. Voorlopige tabellen afl. 2, 3. K.N.N.V., Hoogwoud.

PHLLIPPI, G. (1968): Zur Kenntnis der Zwergbinsengesellschaften (Ordnung der Cyperetalia fusci) des Oberrheingebietes. Veröff. Landesstelle Naturschutz Landschaftspfl. Baden-Württemberg 36: 65-130.

Pietsch, W. (1973): Beitrag zur Gliederung der europäischen Zwergbinsengesellschaften (IsoëtoNanojuncetea Br-Bl. \& Tx. 1943). Vegetatio 28: 401-438.

Raunkiaer, C. (1904): Om biologiske Typer, med Hensyn til Planternes Tilpasning at overleve ugunstige Aarstider. Bot. Tidsskr. 26: XIV.

- (1934): The life forms of plants and statistical plant geography. Oxford Univ. Press, Oxford.

TüXEN, R. \& W. LOHMEYER (1962): Ueber Untereinheiten und Verflechtungen von Pflanzengesellschaften. Mitt. flor-soz. Arbeitsgem. N.F. 9: 53-56.

- \& V. WeSthofF (1963): Saginetea maritimae, eine Gesellschaftsgruppe im wechselhalinen Grenzbereich der europäischen Meeresküsten. Mitt. flor.-soz. Arbeitsgem. N.F. 10: $116-129$.

WERGER, M. J. A. (1978): Vegetation structure in the southern Kalahari. J. Ecol. 66: 933-941.

WESTHOFF, V. (1947): The vegetation of dunes and salt marshes of the Dutch islands of Terschelling, Vlieland and Texel. Thesis Utrecht.

- \& E. VAN Der MaArel (1973): The Braun-Blanquet Approach. In: Handbook of Vegetation Science V: Ordination and Classification of Communities (R. H. WhITTAKER ed.). Junk, The Hague, pp. 617-726.

— \& M. F. Mörzer Bruyns (1956): De groeiplaats van Scirpus americanus Pers. op het groene strand bij West-Terschelling. Acta Bot. Neerl. 5: 344-354.

WhItTAKer, R. H. (1962): Classification of natural communities. Bot. Review 28 : 1-239.

- (1977): Animal effects on plant species diversity. In: Vegetation und Fauna, Ber. int. Symp. Int. Ver. Vegetationskunde, Rinteln (R. Tüxen ed). Cramer, Vaduz, pp. 409-425. 